\title{
Validation and application of a cryogenic vacuum extraction system for soil and plant water extraction for isotope analysis
}

\author{
N. Orlowski ${ }^{1}$, H.-G. Frede ${ }^{1}$, N. Brüggemann ${ }^{2}$, and L. Breuer ${ }^{1}$ \\ ${ }^{1}$ Research Centre for BioSystems, Land Use and Nutrition (IFZ), Institute for Landscape Ecology and \\ Resources Management (ILR), Justus-Liebig-University Giessen (JLU), Giessen, Germany \\ ${ }^{2}$ Forschungszentrum Jülich GmbH, Institute of Bio- and Geosciences - Agrosphere (IBG-3), Jülich, Germany \\ Correspondence to: N. Orlowski (natalie.orlowski@umwelt.uni-giessen.de)
}

Received: 27 February 2013 - Revised: 14 October 2013 - Accepted: 28 October 2013 - Published: 13 November 2013

\begin{abstract}
Stable isotopic analysis of water in plant, soil, and hydrological studies often requires the extraction of water from plant or soil samples. Cryogenic vacuum extraction is one of the most widely used and accurate extraction methods to obtain such water samples. Here, we present a new design of a cryogenic vacuum extraction system with 18 extraction slots and an innovative mechanism to aerate the vacuum system after extraction. This mobile and extendable multi-port extraction system overcomes the bottleneck of time required for capturing unfractionated extracted water samples by providing the possibility to extract a larger number of samples per day simultaneously. The aeration system prevents the loss or mixture of water vapor during defrosting by purging every sample with high-purity nitrogen gas. A set of system functionality tests revealed that the extraction device guarantees stable extraction conditions with no changes in the isotopic composition of the extracted water samples. Surprisingly, extractions of dried and rehydrated soils showed significant differences of the isotopic composition of the added water and the extracts. This observation challenges the assumption that cryogenic extraction systems to fully extract soil water. Furthermore, in a plant water uptake study different results for hydrogen and oxygen isotope data were obtained, raising problems in the definition from which depths plants really take up water. Results query whether the well-established and widely used cryogenic vacuum distillation method can be used in a standard unified method of fixed extraction times as it is often done.
\end{abstract}

\section{Introduction}

During the past decades, stable water isotopes as natural tracers have become a common tool in plant ecological and pedological research. Isotopic fractionation occurring during evaporation and condensation of water leads to observable variations of deuterium and oxygen isotopic composition in natural waters and its use as natural tracers (AraguásAraguás et al., 1995; Unkovich et al., 2001).

In plant ecology stable water isotopes provide a powerful method for determining seasonal changes in plant water uptake (Corbin et al., 2005; Eggemeyer et al., 2009; Butt et al., 2010; Liu et al., 2010), intra- and interspecific resource competition of plants (Williams and Ehleringer, 2000; Yang et al.,
2011), partitioning evaporation and transpiration (Wang and Yakir, 2000; Phillips and Gregg, 2003; Rothfuss et al., 2010, 2012), partitioning of water resources between plants (Stratton et al., 2000; Rossatto et al., 2012), and community wateruse patterns or the zones of root activity in soils (Ehleringer and Dawson, 1992; Thorburn and Ehleringer, 1995; Dawson and Pate, 1996; Liu et al., 2011). Plant water uptake is considered as a non-fractionating process (Wershaw et al., 1966; Dawson and Ehleringer, 1991; Walker and Richardson, 1991; Thorburn et al., 1993; Dawson and Ehleringer, 1993) for non-saline conditions (Lin and Sternberg, 1993), implying that the isotopic signature of the source water remains the same during soil water uptake and water transport through plants (White et al., 1985). Thus, it can be utilized to trace 
back the origin (i.e. soil depth) of water in non-transpiring plant tissues.

In soil isotopic research, potential applications are the examination of soil water movements (Barnes and Allison, 1988; Gazis and Feng, 2004; Song et al., 2009; Brooks et al., 2009) or the quantification of phreatic evaporation (Brunner et al., 2008). To determine the isotopic signature of water, it is necessary to separate or extract the water from other components of the sample material (plant roots, stems and leaves, soil). In recent decades, several extraction methods have been developed: azeotropic distillation with various toxic substances such as toluene, hexane, and kerosene (Revesz and Woods, 1990; Thorburn et al., 1993), mechanical squeezing (Wershaw et al., 1966; White et al., 1985), cryogenic vacuum extraction (Dalton, 1988; Dawson and Ehleringer, 1993; Sala et al., 2000; West et al., 2006; Goebel and Lascano, 2012), the batch-method for stem water extraction (Vendramini and Sternberg, 2007), the modified vacuum extraction technique of Koeniger et al. (2011), centrifugation with or without immiscible heavy liquids (Mubarak and Olsen, 1976; Batley and Giles, 1979; Barrow and Whelan, 1980; Peters and Yakir, 2008) as well as different equilibrium techniques especially for soil samples (Scrimgeour, 1995; Hsieh et al., 1998; McConville et al., 1999; Koehler et al., 2000; Wassenaar et al., 2008). Out of these, cryogenic vacuum extraction is the most widely utilized method (Ingraham and Shadel, 1992; West et al., 2006; Vendramini and Sternberg, 2007; Koeniger et al., 2011).

During cryogenic vacuum extraction the plant or soil material is heated in a tube under a defined vacuum. The sample water evaporates and the evolved vapor is frozen in a cryogenic (liquid nitrogen) trap (Ingraham and Shadel, 1992). After defrosting the sample, its water isotopic signature can be analyzed. Previous studies comparing diverse extraction methods have shown that cryogenic vacuum extraction provides similar, consistent, and high precision results - except for dry soils with a high proportion of heavily bound water and soils containing hydrated salts, such as gypsum (Ingraham and Shadel, 1992; Walker et al., 1994; Araguás-Araguás et al., 1995; Kendall and McDonnell, 1998; Vendramini and Sternberg, 2007). However, cryogenic extraction requires a complex vacuum system and the duration of the extraction process is much longer than for azeotropic distillation or centrifugation methods (Vendramini and Sternberg, 2007).

The aim of this study is to present a vacuum-tight, reliable, and user-friendly cryogenic vacuum extraction system, mainly consisting of standard off-the-shelf material with a modular, extendable design enabling a high sample throughput. The device is equipped with a new mechanism to aerate the vacuum system after water extraction. Due to its flexible setup, the system is easily transportable and can also be used at field sites with power supply. After a description of the technical setup, we show the results of a set of functionality tests that prove the system's reliability, reproducibility, and stability of extraction conditions. Finally, we applied the cryogenic vacuum extraction method to soil and plant samples, which raised critical questions for further research.

\section{Materials and methods}

\subsection{Technical description and extraction methodology}

The distillation system utilized in this study consists of a vacuum manifold with six independent extraction lines, each comprising three extraction-collection units, resulting in a total of 18 extraction slots (Figs. 1 and 2). A detailed parts list is provided in Table A1.

These independent extraction lines are mainly composed of different types of Swagelok ${ }^{\circledR}$ fittings (Swagelok Company, Solon, OH, US), flanges, and flexible hoses (Rettberg ${ }^{\circledR}$, Rettberg Inc., Göttingen, DE) (Fig. 2). The vacuum is generated by a two-stage rotary vane pump (Edwards ${ }^{\circledR}, \mathrm{RV} 5$, Edwards Inc., Kirchheim, DE) and monitored by a PIRANI ${ }^{\circledR}$ vacuum gauge (VAP-5, Vacuubrand Inc., Wertheim, DE) at the end of the manifold. Additional interchangeable vacuum gauges are attached to two out of six extraction lines (DCP $3000+$ VSK 3000, Vacuubrand Inc., Wertheim, DE) (Fig. 2). The vacuum can be separately applied or shut off via diaphragm valves (Fig. 2), which enables independent application of the units. A high-purity nitrogen purging system is realized by attaching additional diaphragm vales to each extraction line and joining them to a dry $\mathrm{N}_{2}$ gas source (Fig. 2).

To extract water from soils or plants, the vacuum manifold is pre-evacuated to draw out possible atmospheric water contamination. The extraction tubes are filled with frozen sample material, and connected to the extraction lines together with the U-tubes (collection units). To fix the sample material in the tubes, avoiding a spread of sample material throughout the extraction system, fleece (Fackelmann Inc, Hersbruck, DE) is packed on top of each sample. During sample fixing care is required to avoid getting filaments of fleece between the connections disturbing vacuum-tightness. A previous test showed that fleece is suitable to fix the sample material and, moreover, does not hold residual water contaminating the sample. Afterwards, the entire system is evacuated to a pressure of $0.3 \mathrm{~Pa}$. Subsequently, the diaphragm valves isolating the extraction lines from the vacuum manifold are closed. During the entire extraction process, the samples are heated to $90^{\circ} \mathrm{C}$, leading to the evaporation of water, which is successively trapped in the frozen U-tubes. In order to avoid isotope fractionation, the extraction process has to be conducted until completion, as fractionation effects appear for the more strongly bound water towards the end of the extraction period (Raleigh distillation) (Kendall and McDonnell, 1998).

At the end of the water extraction, residual water in the angular fittings connecting the extraction tubes with the Utubes is evaporated by heating the fittings with a heat gun to $\sim 90^{\circ} \mathrm{C}$. The extracted water is purged by high-purity nitrogen gas and every tube is removed from the system. During 


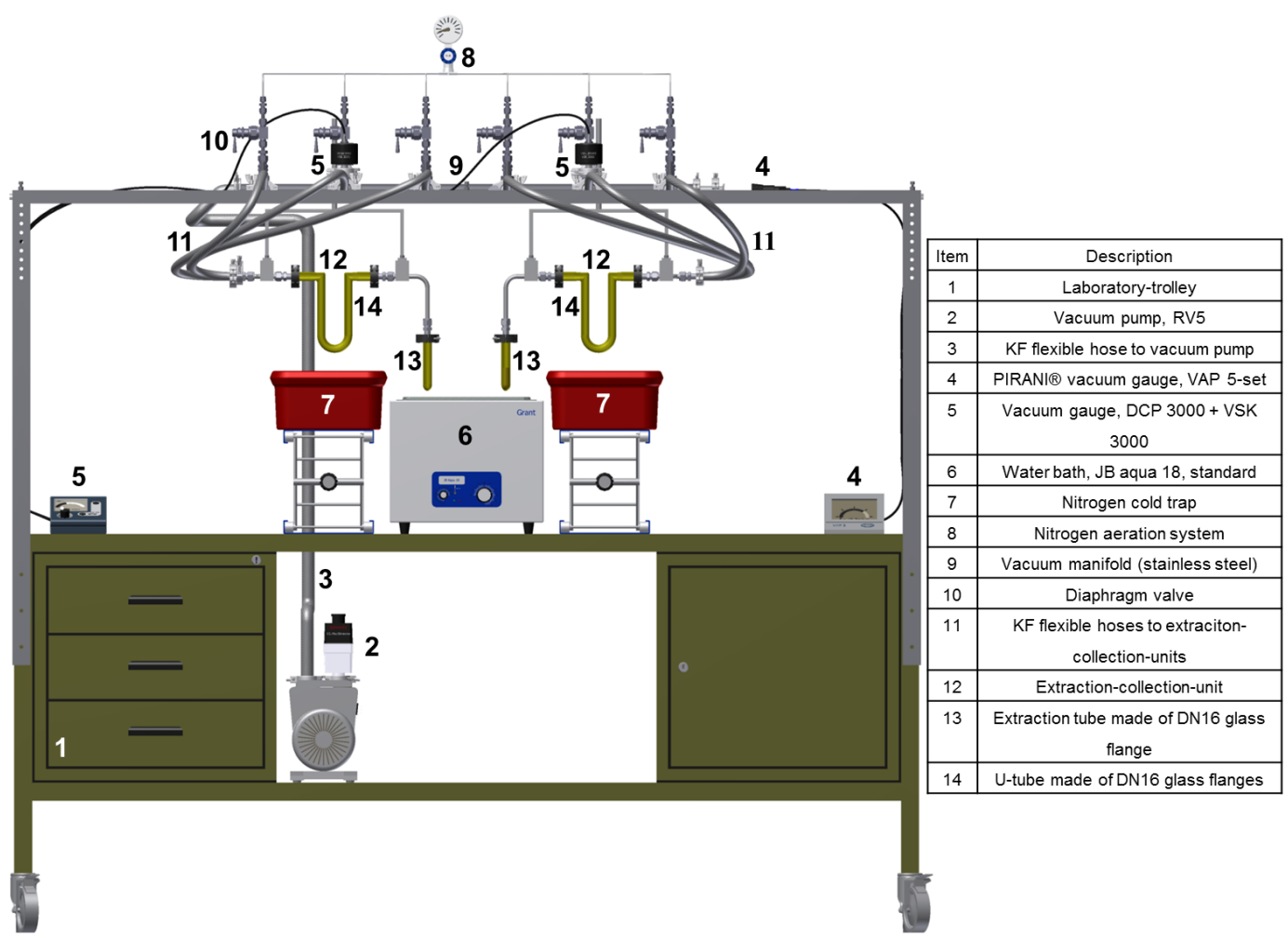

Figure 1. Schematic of the cryogenic vacuum extraction system fixed with a stainless steel frame to a laboratory trolley.

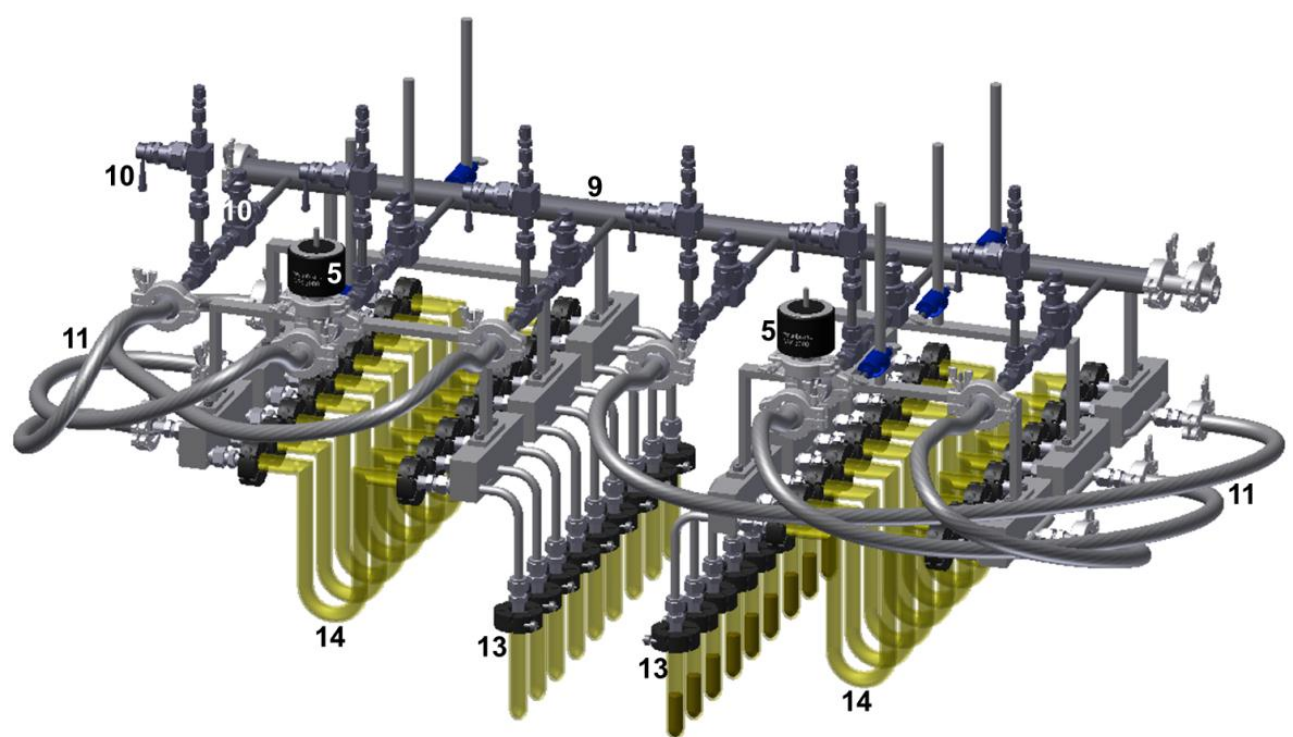

\begin{tabular}{|c|c|}
\hline Item & Description \\
\hline 1 & Laboratory-trolley \\
\hline 2 & Vacuum pump, RV5 \\
\hline 3 & KF flexible hose to vacuum pump \\
\hline 4 & PIRANI@ vacuum gauge, VAP 5-set \\
\hline 5 & Vacuum gauge, DCP $3000+$ VSK \\
& 3000 \\
\hline 6 & Water bath, JB aqua 18, standard \\
\hline 7 & Nitrogen cold trap \\
\hline 8 & Nitrogen aeration system \\
\hline 9 & Vacuum manifold (stainless steel) \\
\hline 10 & Diaphragm valve \\
\hline 11 & KF flexible hoses to extraciton- \\
& collection-units \\
\hline 12 & Extraction-collection-unit \\
\hline 13 & $\begin{array}{c}\text { Extraction tube made of DN16 glass } \\
\text { flange }\end{array}$ \\
\hline 14 & U-tube made of DN16 glass flanges \\
\hline
\end{tabular}

Figure 2. Detail view of the extraction manifold with six extraction lines and 18 extraction-collection units. Parts list is provided in Table A1.

thawing the U-tubes are sealed with silicon plugs. Finally, the extracted water is pipetted from the U-tubes into glass vials $(2 \mathrm{~mL})$ for isotopic analysis. All water and soil samples utilized in the following experiments were sealed with Parafilm ${ }^{\circledR}$ and stored light-excluded in vials or amber glass tubes at $7^{\circ} \mathrm{C}$.

\subsection{Functionality tests of extraction system}

To prove the system's reliability, reproducibility, and stability of extraction conditions, functionality tests were conducted (Table 1), which are supposed to serve as a basis for future extraction systems validations. 
For a simple implementation and proper comparability of the results, three isotopically different types of pure water were chosen as testing materials for experiment \#1 to \#3: water from the Schwingbach creek $\left(\delta^{2} \mathrm{H}:-56.10 \%\right.$, $\delta^{18} \mathrm{O}:-8.46 \%$ ), local precipitation $\left(\delta^{2} \mathrm{H}:-1.49 \%\right.$, $\delta^{18} \mathrm{O}$ : $-0.99 \%$ ) , and tap water $\left(\delta^{2} \mathrm{H}:-56.74 \% o, \delta^{18} \mathrm{O}:-9.28 \% o\right)$. Precision of analyses was $\pm 0.60 \%$ for $\delta^{2} \mathrm{H}$ and $\pm 0.20 \%$ o for $\delta^{18} \mathrm{O}$ (LGR, 2013) (see Sect. 2.5). All waters were collected on 28 August 2009. Each extraction tube was filled with $10 \mathrm{~mL}$ test water. The extraction was complete when all test water had been transferred into the collection tubes.

Experiment \#1 was conducted to test a potential effect of the applied cryogenic vacuum extraction procedure itself. Therefore, a water extraction with pure local tap water was performed and the isotopic signatures of untreated $(N=5)$ vs. extracted local tap water $(N=6)$ were statistically tested (Table 1).

For testing the effect of high-purity nitrogen purging on the extracted water isotopic signature, local tap water (experiment \#2a) and Schwingbach creek water (experiment \#2b) was extracted and purged with nitrogen gas (Table 1). Again, extracted water samples $(N=6)$ were compared with untreated, unpurged water samples $(N=5)$.

For experiment \#3 local precipitation $(N=3)$ and water from the Schwingbach creek $(N=3)$, which strongly differ isotopically, were filled alternately into six extraction tubes to test if cross-contamination between the extraction lines occurred (Table 1).

\subsection{Extraction process experiments}

Testing the system's capability to recover water of known isotopic composition, experiments listed in Table 1 were performed. Each type of soil was sieved ( $2 \mathrm{~mm})$, homogenized, oven-dried $\left(105^{\circ} \mathrm{C}, 24 \mathrm{~h}\right)$, and rehydrated with local tap water $\left(\delta^{2} \mathrm{H}:-59.49 \pm 0.79 \% o, \delta^{18} \mathrm{O}:-8.56 \pm 0.22 \% o\right)$. Beside the Luvisol sample (highly clayey silt, $\mathrm{pH}: 7.0 \pm 0.0$ ), standard soils from the state research institute for agriculture (LUFA, Speyer, DE) were chosen as testing materials. The soils from LUFA 1 to 4 represent a gradient from sandy to loamy texture with increasing $\mathrm{pH}$-values (LUFA 1: silty sand, $\mathrm{pH}$ : $5.1 \pm 0.3$; LUFA 2: loamy sand, $\mathrm{pH}: 5.5 \pm 0.2$; LUFA 3 : silty sand, $\mathrm{pH}$ : $6.7 \pm 0.3$; and LUFA 4: clayey loam, pH: $7.1 \pm 0.2$ ). After rehydrating, soils were equilibrated for $24 \mathrm{~h}$ to ensure uniform water contents. For experiment \#5b the extraction process was interrupted after 15 and $60 \mathrm{~min}$. U-tubes were demounted, slowly defrosted, and an intermediate isotope sample $(2 \mathrm{~mL})$ was taken. Afterwards, the U-tubes with the remaining water were re-attached to the system and the water extraction was continued.

The isotopic signatures of added untreated tap water were statistically compared with extracted water isotopic signatures or groups of different extraction durations and approaches. Before rehydration, a $48 \mathrm{~h}$ oven-drying $\left(105^{\circ} \mathrm{C}\right)$ was conducted to check if soil samples had been dried to con- stant mass containing no residual water contaminating the added isotopic signature. To check if the added water was entirely extracted, all samples were weighed (PM200, MettlerToledo Inc., Giessen, DE; precision $0.001 \mathrm{~g}$ ) before and after water extraction, and after an additional oven-drying ( $24 \mathrm{~h}$, $105^{\circ} \mathrm{C}$ ) of the extracted samples.

\subsection{Applying cryogenic extraction to investigate crop water uptake}

For herbaceous species like forbs and grasses, Barnard et al. (2006) identified the root crown tissue as the most suitable part of the plant to analyze the isotopic signature of the absorbed water. The root tissue itself is not a reliable identifier to quantify the actual source of the water as the rooting depth and the source of the water may differ (Thorburn and Ehleringer, 1995). Previous studies also analyzed stem or culm material exploring the water use by vegetation (Corbin et al., 2005; Gat et al., 2007; Rossatto et al., 2013). For this reason, a simultaneous probing of the root crown, stem tissue, and the actual isotopic signature of the soil water at different depths seemed to be the most reliable method to identify the source of water uptake. We conducted a pot experiment with two common field crops, i.e. barley (Hordeum vulgare L. cv. Barke) and wheat (Triticum aestivum, Xenos) under controlled-environment conditions to test if there is an impact of:

1. harvest time on the isotopic signature of sampled plant tissue (stem and root crown) water of two crop species (barley and wheat);

2. harvest time on water uptake zones of these crop species;

3. analyzed isotopes (either hydrogen or oxygen) on investigating plants' source water.

Plants were sown as monocultures on 3 December 2010, in free-draining pots $(16 \times 16 \times 16 \mathrm{~cm})$ filled with $4 \mathrm{~L}$ conventional potting soil (Fruhstorfer Erde, Hawita Group Inc., Vechta, DE). For every crop type 54 replicates were planted, each in a single pot, resulting in a sum of 108 pots. Plants were grown in the greenhouse with a $14 \mathrm{~h}$ photoperiod, day and night temperatures of 20 and $14{ }^{\circ} \mathrm{C}$, respectively. Irrigation with local tap water was carried out three times per week until saturation, while excess water could freely drain. Irrigation water was sampled each time for isotopic analysis (200 times in total). The isotopic signature of irrigation water did not differ significantly between first and second harvest (means and standard deviations for the first $(N=100)$ and second harvest $(N=100)$, respectively, $\delta^{2} \mathrm{H}$ : $-60.29 \pm 1.26 \%$ and $-60.16 \pm 1.27 \%$; $\delta^{18} \mathrm{O}:-8.85 \pm 0.35 \%$ o and $-8.92 \pm 0.27 \%$ o).

On 2 and 3 March 2011, after 91 days, 27 individuals per species were harvested. The second harvest was carried out 
Table 1. Description of the functionality tests \#1 to \#3 and the extraction process experiments \#4 to \#6.

\begin{tabular}{|c|c|c|c|c|c|}
\hline \multicolumn{6}{|c|}{ Functionality tests } \\
\hline Experiment & Description & Testing material & $\mathrm{N}$ & & \\
\hline$\# 1$ & Effect of extraction process & Local tap water & $\begin{array}{l}\text { Untreated: } 5 \text {, } \\
\text { extracted: } 6\end{array}$ & & \\
\hline$\# 2 \mathrm{a}$ & $\begin{array}{l}\text { Effect of high-purity } \\
\text { nitrogen purging }\end{array}$ & Local tap water & $\begin{array}{l}\text { Untreated: } 5 \text {, } \\
\text { extracted and } \\
\text { purged: } 6\end{array}$ & & \\
\hline$\# 2 \mathrm{~b}$ & $\begin{array}{l}\text { Effect of high-purity } \\
\text { nitrogen purging }\end{array}$ & $\begin{array}{l}\text { Schwingbach creek } \\
\text { water }\end{array}$ & $\begin{array}{l}\text { Untreated: } 5 \text {, } \\
\text { extracted and } \\
\text { purged: } 6\end{array}$ & & \\
\hline$\# 3$ & Cross-contamination & $\begin{array}{l}\text { Local precipitation, } \\
\text { Schwingbach creek } \\
\text { water }\end{array}$ & $\begin{array}{l}\text { Untreated: } 5 \text {, } \\
\text { extracted: } 3 \\
\text { per type of } \\
\text { water }\end{array}$ & & \\
\hline \multicolumn{6}{|c|}{ Extraction process experiments } \\
\hline Experiment & Description & Testing material & $\begin{array}{l}\text { Water content } \\
{[\%]}\end{array}$ & $\begin{array}{l}\text { Extraction } \\
\text { duration [min] }\end{array}$ & $\mathrm{N}$ \\
\hline \#4 & $\begin{array}{l}\text { Water recovery of } \\
\text { rehydrated soils }\end{array}$ & Ah-horizon of Luvisol & 10 & 180 & 18 \\
\hline$\# 5 \mathrm{a}$ & Effect of extraction time & Ah-horizon of Luvisol & 20 & $\begin{array}{l}15,30,45,60, \\
120,180\end{array}$ & 3 per duration \\
\hline$\# 5 \mathrm{~b}$ & Effect of extraction time & Ah-horizon of Luvisol & 20 & $\begin{array}{l}180 ; \text { interruption } \\
\text { after } 15 \text { and } 60\end{array}$ & 18 \\
\hline \#6 & Effect of soil type & $\begin{array}{l}\text { Ah-horizon of Luvi- } \\
\text { sol, LUFA soil } 1 \text { to } 4\end{array}$ & 20 & $\begin{array}{l}15,30,45,60, \\
120,180\end{array}$ & 3 per duration \\
\hline
\end{tabular}

on 6 and 7 April 2011, after 126 days. At every harvest the following samples were taken: the lower $10 \mathrm{~cm}$ of the stem (after removal of the outer sheath), root crown, and an aliquot of the upper $8 \mathrm{~cm}$ and the lower $8 \mathrm{~cm}$ of the soil column (after removal of the roots). Plant and soil samples were immediately frozen until water extraction. Soils were extracted for $180 \mathrm{~min}$ and plant tissues for $90 \mathrm{~min}$.

\subsection{Isotopic analysis}

Isotopes were analyzed at the Institute for Landscape Ecology and Resources Management (JLU Giessen, DE) according to the IAEA standard procedure (Newman et al., 2012) using a Los Gatos Research DLT-100-Liquid Water Isotope Analyzer (Los Gatos Research Inc., Mountain View, CA, USA). The DLT-100 is based on off-axis integrated cavity output spectroscopy (OA-ICOS), which enables a simultaneously quantification of $\delta^{18} \mathrm{O}$ and $\delta^{2} \mathrm{H}$ isotopic signatures. OA-ICOS measures with the same or even better precision than conventional stable isotope-ratio mass spectrometers (Lis et al., 2008; Penna et al., 2010). Isotopic ratios are reported in per mil $(\% o)$ relative to a standard, i.e. the Vienna Standard Mean Ocean Water (VSMOW) (Craig, 1961):

$\delta^{2} \mathrm{H}$ or $\delta^{18} \mathrm{O}=\left(\frac{R_{\text {sample }}}{R_{\text {standard }}}-1\right) \times 1000$.

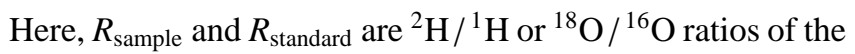
sample and standard, respectively. Precision of analyses was $\pm 0.60 \%$ o for $\delta^{2} \mathrm{H}$ and $\pm 0.20 \%$ or for $\delta^{18} \mathrm{O}$ (LGR, 2013).

Leaf water extracts typically contain a high fraction of organic contaminations (West et al., 2010), which might lead to spectral interferences when using isotope ratio infrared absorption spectroscopy (Leen et al., 2012), causing erroneous isotope values (Schultz et al., 2011). Therefore, isotopic data of plant water extracts were checked for spectral interferences using the Spectral Contamination Identifier (LWIASCI) post-processing software (Los Gatos Research Inc.). No sample was found to be contaminated with organics.

\subsection{Statistical analysis}

All statistical analyses were performed utilizing IBM SPSS Statistics (Version 19.0, SPSS Inc., Chicago, IL, US). First, the data were tested for normal distribution. Subsequently, $t$ tests were performed for experiments \#1 and \#2, whereas ANOVAs with Tukey-HSD tests were conducted for experiment \#3 to \#6 $(p \leq 0.05)$. For the plant water uptake study, Multivariate Analyses of Variances (MANOVAs) were done and Tukey-HSD tests were run to determine significant differences between groups $(p \leq 0.05)$. 
Table 2. Means and standard errors for $\delta^{2} \mathrm{H}$ and $\delta^{18} \mathrm{O}$ values of system functionality tests \#1 to \#3 (superscripts indicate significant differences, $p<0.05)$.

\begin{tabular}{lll}
\hline & $\delta^{2} \mathrm{H}[\% \circ]$ & $\delta^{18} \mathrm{O}[\% \circ]$ \\
\hline Experiment \#1: Effect of extraction process & & \\
\hline Extracted local tap water & $-57.49 \pm 0.58^{\mathrm{a}}$ & $-9.40 \pm 0.12^{\mathrm{a}}$ \\
Untreated local tap water & $-56.74 \pm 0.36^{\mathrm{a}}$ & $-9.28 \pm 0.11^{\mathrm{a}}$ \\
\hline Experiment \#2a: Effect of high-purity nitrogen purging & & \\
\hline Local tap water without nitrogen purging & $-57.66 \pm 0.60^{\mathrm{a}}$ & $-9.38 \pm 0.12^{\mathrm{a}}$ \\
Local tap water with nitrogen purging & $-58.51 \pm 0.20^{\mathrm{a}}$ & $-9.33 \pm 0.03^{\mathrm{a}}$ \\
\hline Experiment \#2b: Effect of high-purity nitrogen purging & & \\
\hline Untreated Schwingbach water & $-56.10 \pm 0.72^{\mathrm{a}}$ & $-8.46 \pm 0.14^{\mathrm{a}}$ \\
Schwingbach water with nitrogen purging & $-55.52 \pm 0.28^{\mathrm{a}}$ & $-8.76 \pm 0.11^{\mathrm{a}}$ \\
\hline Experiment \#3: Cross-contamination & & \\
\hline Untreated local precipitation & $-1.83 \pm 0.21^{\mathrm{a}}$ & $-1.24 \pm 0.19^{\mathrm{a}}$ \\
Extracted local precipitation & $-1.53 \pm 0.10^{\mathrm{a}}$ & $-1.26 \pm 0.03^{\mathrm{a}}$ \\
Untreated Schwingbach water & $-56.10 \pm 0.72^{\mathrm{b}}$ & $-8.46 \pm 0.14^{\mathrm{b}}$ \\
Extracted Schwingbach water & $-56.69 \pm 0.43^{\mathrm{b}}$ & $-8.90 \pm 0.12^{\mathrm{b}}$ \\
\hline
\end{tabular}

\section{Results and discussion}

\subsection{Functionality tests of extraction system}

The functionality and extraction process tests \#1 to \#6 should serve as guidance for future rigorous validations of extraction systems. In the past, the performance of extraction systems was in most cases merely verified through water extractions from soils of various grain size, water contents, or extraction duration (Ingraham and Shadel, 1992; Walker et al., 1994; Araguás-Araguás et al., 1995; West et al., 2006; Koeniger et al., 2011), separately tested for the system's extraction ports (Goebel and Lascano, 2012). However, none of the studies tested the functionality of a vacuum extraction system in the same detail as performed here.

Experiment \#1 demonstrated that the water extraction procedure did not lead to significant differences in isotopic signatures between untreated and extracted tap water samples $\left(\delta^{2} \mathrm{H}: p=0.32, \delta^{18} \mathrm{O}: p=0.52\right)$ (Table 2).

Purging with high-purity nitrogen (experiments \#2a and \#2b) to prevent a possible isotopic exchange of extracted water with air did also not result in significant differences in isotopic composition, neither for local tap water $\left(\delta^{2} \mathrm{H}\right.$ : $\left.p=0.22, \delta^{18} \mathrm{O}: p=0.69\right)$ nor for Schwingbach creek water $\left(\delta^{2} \mathrm{H}: p=0.48, \delta^{18} \mathrm{O}: p=0.13\right)$ (Table 2).

In experiment \#3, no significant differences were observed between untreated and extracted samples, neither for precipitation water $\left(\delta^{2} \mathrm{H}: p=0.96, \delta^{18} \mathrm{O}: p=1.00\right)$ nor for Schwingbach creek water $\left(\delta^{2} \mathrm{H}: p=0.75, \delta^{18} \mathrm{O}: p=0.11\right)$. Statistically highly significant differences between precipitation and Schwingbach water even after extraction $(p=0.00)$ were found, demonstrating that there was no cross-contamination between the six extraction lines (Table 2).

\subsection{Extraction process experiments}

\subsubsection{Experiment 4: water recovery of rehydrated soils}

A simple, yet informative experiment to test the feasibility of the extraction system was to recover water of known stable isotopic composition that had been introduced to previously dried soil. Surprisingly, the isotopic signature of the added water could be recovered neither for hydrogen nor for oxygen (Fig. 3), despite a long extraction time of $180 \mathrm{~min}$ and a vacuum of $0.3 \mathrm{~Pa}$.

Previous studies (Ingraham and Shadel, 1992; Walker et al., 1994; Araguás-Araguás et al., 1995; Kendall and McDonnell, 1998) indicated that extracting water from clay soils could be problematic due to interactions between pore water and weakly bound water in the clay matrix. Therefore, an additional $48 \mathrm{~h}$ of oven-drying of the untreated Luvisol sample was conducted before rehydration to check for residual water. Comparing the water content after $24 \mathrm{~h}$ drying $(24.2 \%)$ with that after $48 \mathrm{~h}$ drying $(24.1 \%)(N=3)$ resulted in an additional water loss of $0.11 \%$ on average. This small amount of tightly bound residual water could not have affected the isotopic signature in a way as we observed it. The fraction of residual water in the untreated soil becomes more significant as the quantity of introduced water in terms of water content is small (Walker et al., 1994) - which was not the case in our study with 10 or $20 \%$ water content - or the isotopic signature of the residual water is significantly different from the introduced water. Thus, a memory effect in the soil 


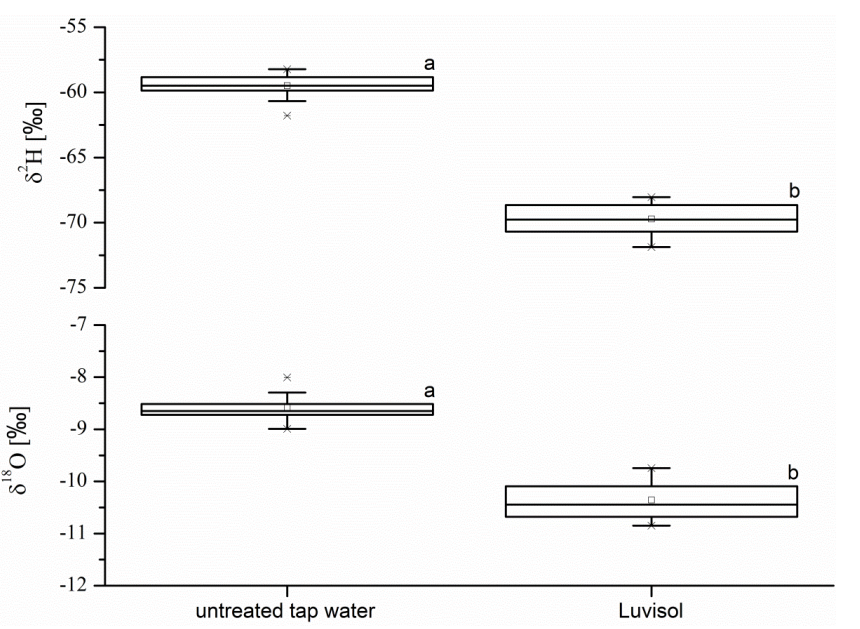

Figure 3. Comparison of isotopic ratios of untreated tap water with water extracted from an oven-dried Luvisol $(180 \mathrm{~min})$ rehydrated with the same tap water. Different letters indicate significant differences $(p<0.05)$.

as found by Koeniger et al. (2011) can be excluded, as hardly any residual water $(0.11 \%)$ was detected in the untreated soil samples. Walker et al. (1994) already stated a temperature dependency of the isotopic signature of the extracted water. Furthermore, even at extraction temperatures $>100^{\circ} \mathrm{C}$ the introduced water in their experiments could not be fully recovered, neither by vacuum extraction nor by other extraction methods (azeotropic and microdistillation). The differences in extraction procedures, i.e. the applied vacuum or the extraction duration, remained unknown in their comparison. In our study, high-temperature extractions could not easily be tested without major rearrangement of the technical setup of the extraction system, for instance in changing the heating element and replacing it with a heated sand bath that facilitates heating of soils to several $100^{\circ} \mathrm{C}$. Further research is needed for fully explaining the observed incomplete recovery of soil water and its effect on soil water isotope studies.

\subsubsection{Experiment 5: effect of extraction time}

For specifying the effect of extraction time on isotopic ratios of extracted water, we conducted two experiments (\#5a and \#5b, see Table 1). For experiment \#5a, the only significant differences in $\delta^{2} \mathrm{H}$ values were found between soil extracted for $15 \mathrm{~min}$ and soil extracted for 60 and $120 \mathrm{~min}$, respectively (Fig. 4a). For $\delta^{18} \mathrm{O}$, four statistical homogenous groups were identified (Fig. 4b). Samples extracted for 60 to $180 \mathrm{~min}$ exhibited somewhat lower mean $\delta^{18} \mathrm{O}$ signatures around $-9 \%$ as compared to the applied water with a $\delta^{18} \mathrm{O}$ of $-8.5 \%$. However, mean values were not significantly different, in contrast to results obtained for $\delta^{2} \mathrm{H}$.

Generally, isotopic values after 15 min extraction time were significantly depleted compared to the original tap water and thus indicated a large fractionation effect. Because of Rayleigh fractionation, we found progressively less negative values towards the end of the extraction process for both isotopes (exception: $\delta^{18} \mathrm{O}$ after $45 \mathrm{~min}$ extraction time). In agreement with the results of West et al. (2006) and Goebel and Lascano (2012), we observed no statistically significant changes in the isotopic signatures for extraction times longer than $30 \mathrm{~min}$ for hydrogen isotopes and $60 \mathrm{~min}$ for oxygen isotopes for this specific soil type. Nevertheless, as already observed in experiment \#4 neither $\delta^{2} \mathrm{H}$ nor $\delta^{18} \mathrm{O}$ of extracted water matched the isotopic signature of the applied water.

In experiment $\# 5 \mathrm{~b}$, no significant differences between the soil samples extracted for 15 and $60 \mathrm{~min}$ were found for both isotopes. However, they differed significantly from the soil samples extracted for $180 \mathrm{~min}$ (Fig. 4c and d). Again, isotopic composition became less depleted with longer extraction times. Most of the water had been extracted during the first $15 \mathrm{~min}$, and decreasing amounts of water were extracted with increasing extraction time. The fraction of light isotopes is known to be extracted first (Kendall and McDonnell, 1998). After 60 min extraction time most of the water had already been removed, resulting in more positive isotopic signatures of the remaining water due to isotopic enrichment.

To test whether the isotopic ratios of extracted water at the same extraction times differed between the extraction experiments \#5a and \#5b, soil samples extracted for 15, 60, and 180 min were compared (Fig. 4, capital letters). Hydrogen isotopic ratios after 60 min extraction time differed significantly between the approaches, with more negative values in experiment \#5b. However, no significant differences in $\delta^{18} \mathrm{O}$ values were found between 15,60 , and $180 \mathrm{~min}$ extraction time in both experiments. Unless all soil samples were homogenized, sample heterogeneity could be a potential source of error, which becomes more important for smaller sample sizes. The greater variance of values in experiment \#5a is most likely associated with a smaller sample size $(N=3)$. However, both approaches showed the same dynamic: isotopic signatures of extracted water approached the tap water signature with increasing extraction time. Therefore, in the following experiments examining the effect of soil type on isotopic signatures of the extracted water, the first approach (experiment \#5a) was implemented due to its higher feasibility and better comparability with other studies.

\subsubsection{Experiment 6: effect of soil type}

To test the hypothesis that particle size distribution affects the tightness of water bound in the soil, five different driedrehydrated soil types were extracted for 15 to $180 \mathrm{~min}$ (approach analogous to experiment \#5a).

The $\delta^{2} \mathrm{H}$ values of Luvisol showed no statistical differences between 15 to 45 , and $180 \mathrm{~min}$, just as for 30 to $180 \mathrm{~min}$ extraction time (Fig. 5). The $\delta^{2} \mathrm{H}$ of water added for rehydration in soil water extracts could not be recovered, in contrast to $\delta^{18} \mathrm{O}$ after 60 to $180 \mathrm{~min}$ extraction time (Fig. 6). For LUFA soil 1 no significant changes in $\delta^{2} \mathrm{H}$ and $\delta^{18} \mathrm{O}$ 

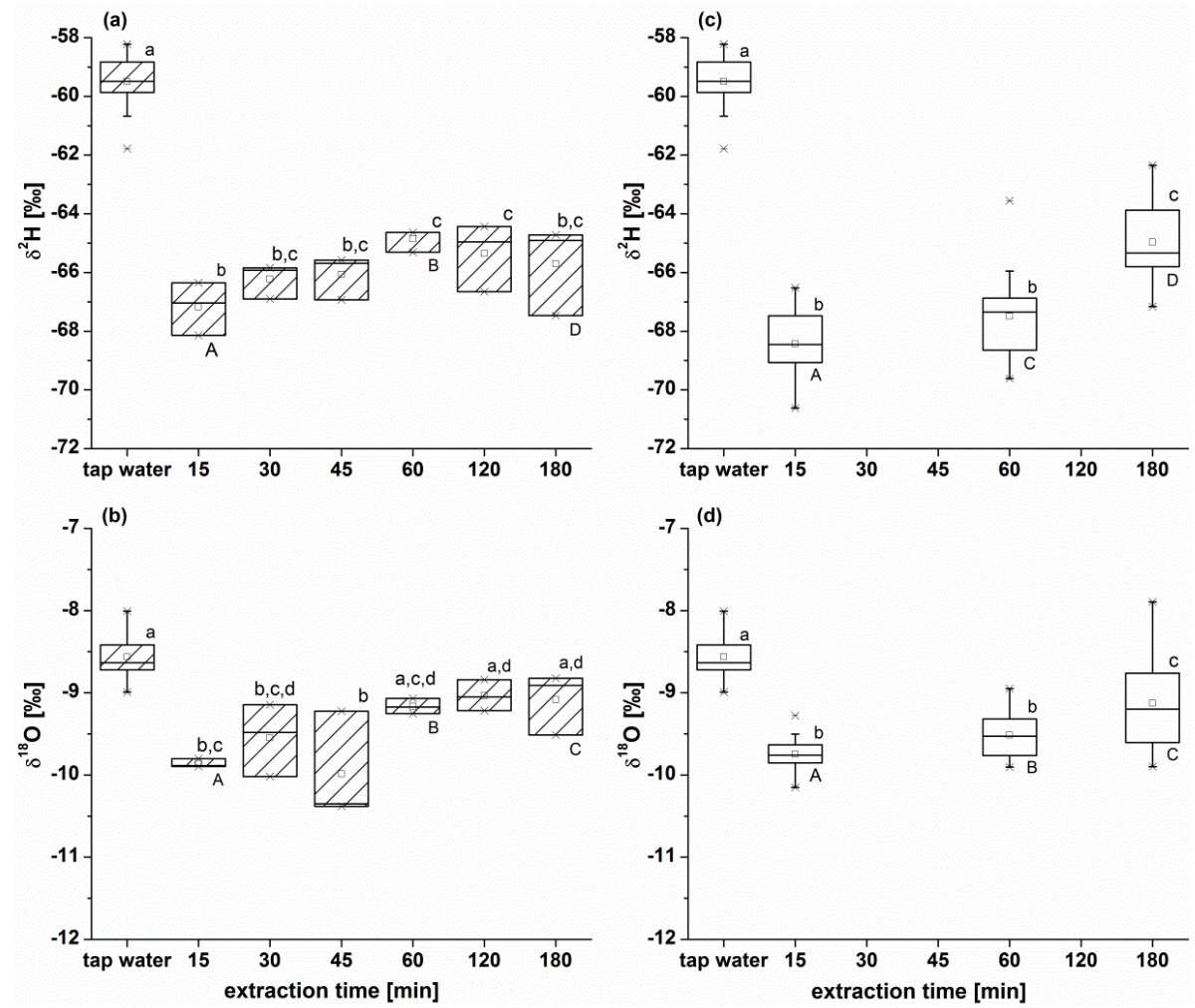

Figure 4. Comparison of isotopic ratios of untreated tap water with water recovered from dried Luvisol rehydrated with the same tap water and extracted increasingly long time intervals. Left panels: experiment \#5a; right panels: experiment \#5b. Different letters indicate significant differences $(p<0.05)$. Small letters indicate intra-experimental comparisons between different extraction times for the same approach; capital letters indicate inter-experimental comparisons between same extraction times for different experimental approaches (\#5a vs. \#5b).

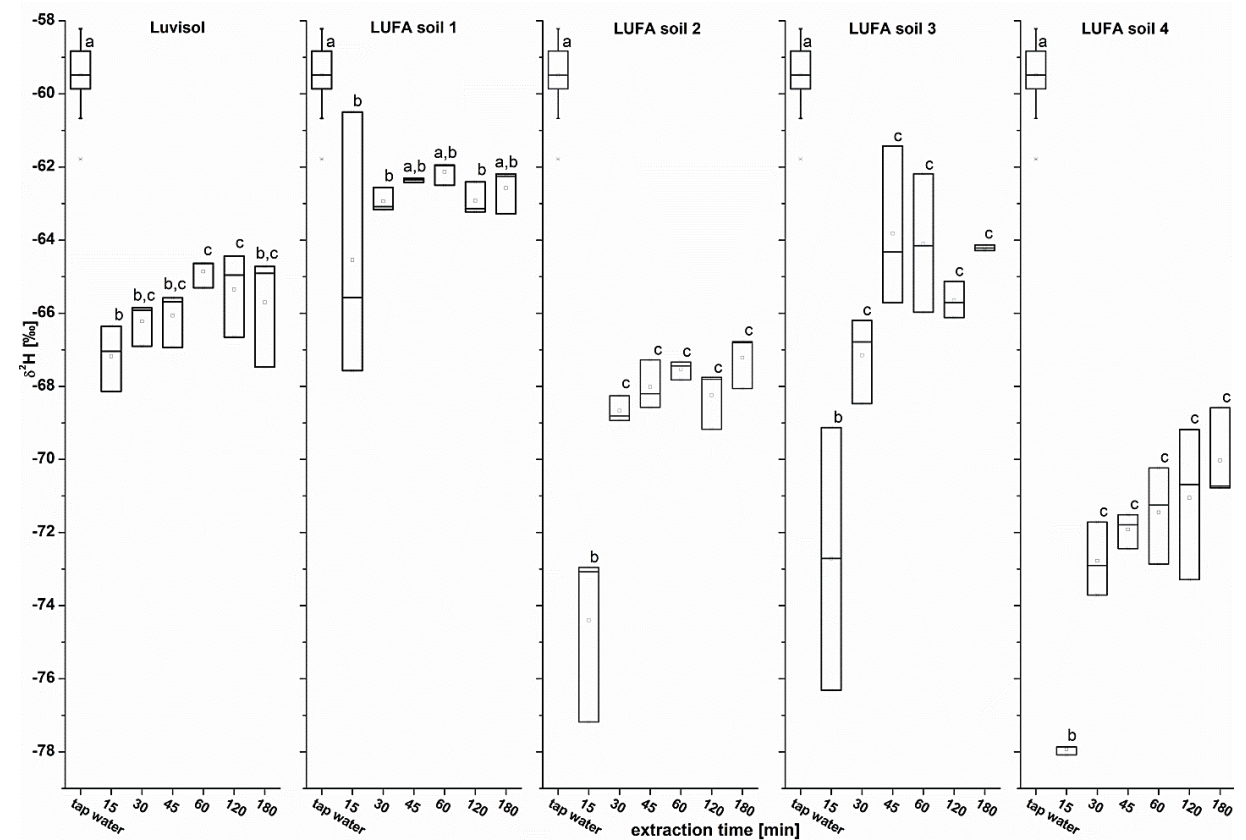

Figure 5. Comparison of $\delta^{2} \mathrm{H}$ values of untreated tap water with water recovered from five different dried soil substrates (Luvisol, LUFA soils 1 to 4 ) rehydrated with the same tap water and extracted for increasingly long time intervals (15 to 180 min). Different letters indicate significant differences $(p<0.05)$. 


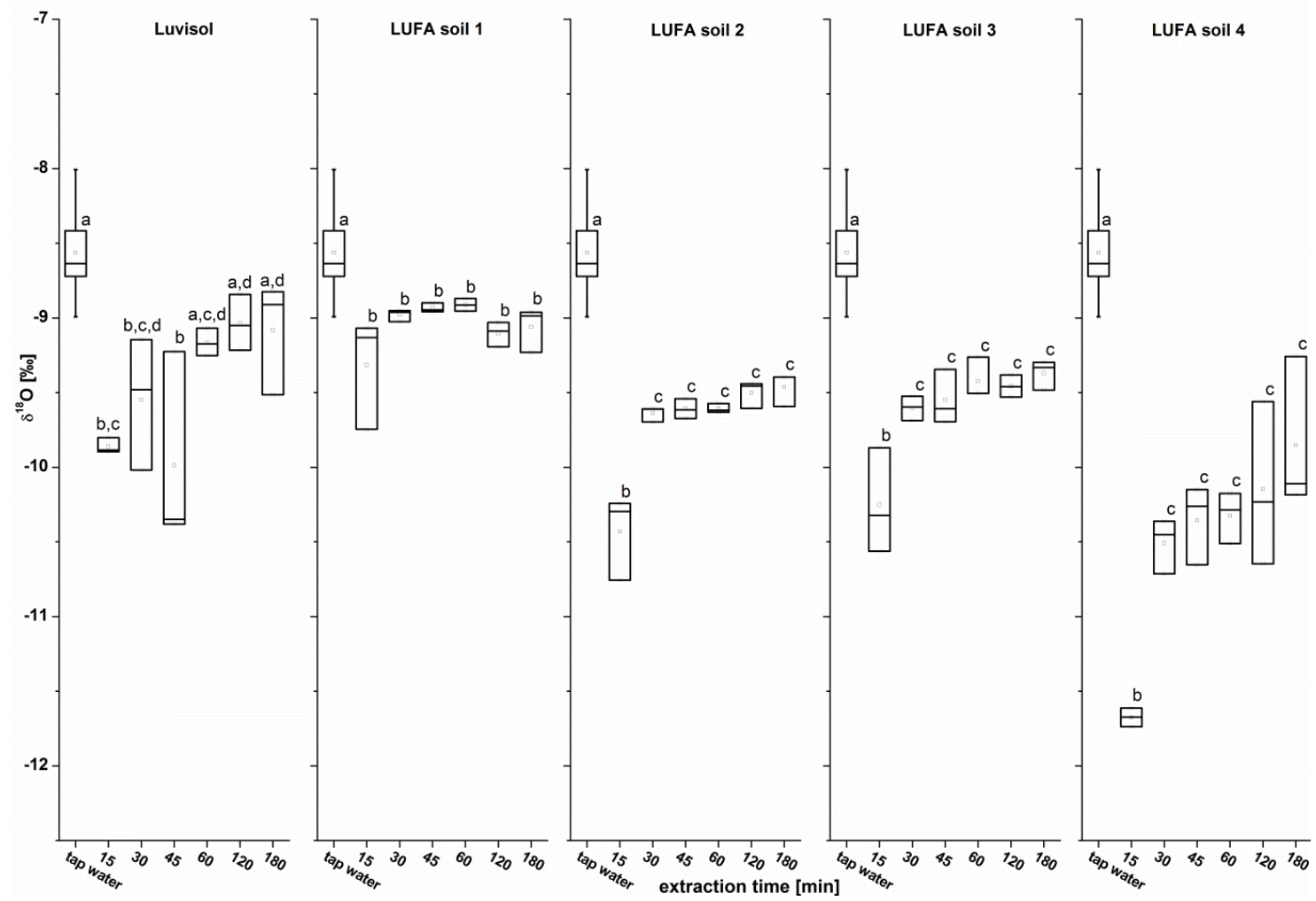

Figure 6. Comparison of $\delta^{18} \mathrm{O}$ values of untreated tap water with water recovered from five different dried soil substrates (Luvisol, LUFA soils 1 to 4 ) rehydrated with the same tap water and extracted for increasingly long time periods (15 to 180 min). Different letters indicate significant differences $(p<0.05)$.

values between 15 to $180 \mathrm{~min}$ extraction time were found (Figs. 5 and 6). For 45, 60, and 180 min extraction time, $\delta^{2} \mathrm{H}$ values of LUFA soil 1 were not significantly different from that of the introduced tap water. Moreover, the $\delta^{18} \mathrm{O}$ values of LUFA soil 1 showed the smallest mean difference $(0.49 \%$ ) from the tap water values. Extracted water isotopic signatures of LUFA soil 2 to 4 exhibited strongly depleted values for both isotopes at $15 \mathrm{~min}$ extraction time (Figs. 5 and 6). Furthermore, these soil types showed the largest differences in both $\delta^{2} \mathrm{H}$ and $\delta^{18} \mathrm{O}$ values in comparison to the isotopic signature of added water. No significant changes in the isotopic signatures of water extracted from LUFA soils 2 to 4 could be observed after 30 to 180 min extraction time, suggesting that 30 min extraction time was sufficient for those soils. Nevertheless, none of LUFA soil 2 to 4 water extracts reflected the original tap water isotopic values.

In contrast to the findings of Koeniger et al. (2011), whose extraction procedure was unable to fully recover water added to clayey and silty soils, tap water $\delta^{18} \mathrm{O}$ values could be recovered from the Luvisol. The isotopic signatures for the silty and clayey LUFA soils 3 and 4 showed the largest range. In contrast, soils with a loamy texture (LUFA soil 2 and 4) showed the highest mean differences from the introduced isotopic signature for both isotopes.
Gravimetric soil water analysis revealed no significant differences in weight between soils before water addition, after water extraction, and after oven-drying of the extracted soils, indicating a complete extraction. Incomplete water extraction in terms of weight was only observed for one sample, with a recovery rate still as high as $99 \%$.

West et al. (2006) determined extraction times to obtain an unfractionated water sample for sandy soils of $30 \mathrm{~min}$, and $40 \mathrm{~min}$ for clay soils, consistent with the results of Goebel and Lascano (2012) who recommended $30 \mathrm{~min}$ extraction duration for a sandy clay loam. Koeniger et al. (2011) applied even shorter extraction times (2.5 to $40 \mathrm{~min}$ ), recovering the original water isotopic signature after $15 \mathrm{~min}$. Our extraction duration of 180 min exceeded the extraction times of the abovementioned studies. The same was true for the applied pressure level $(0.3 \mathrm{~Pa})$, which was at the lower end of other vacuum extraction procedures ranging from $13 \mathrm{~Pa}$ (Goebel and Lascano, 2012), 8.0 Pa (West et al., 2006), 3.07 Pa (Koeniger et al., 2011), 1.3 Pa (Vendramini and Sternberg, 2007 ) to $0.13 \mathrm{~Pa}$ (Peters and Yakir, 2008). We conclude that either longer extraction times ( $>180 \mathrm{~min})$, or higher extraction temperatures $\left(>90^{\circ} \mathrm{C}\right)$, or lower pressures $(<0.3 \mathrm{~Pa})$, or a combination are required to achieve reliable results. 

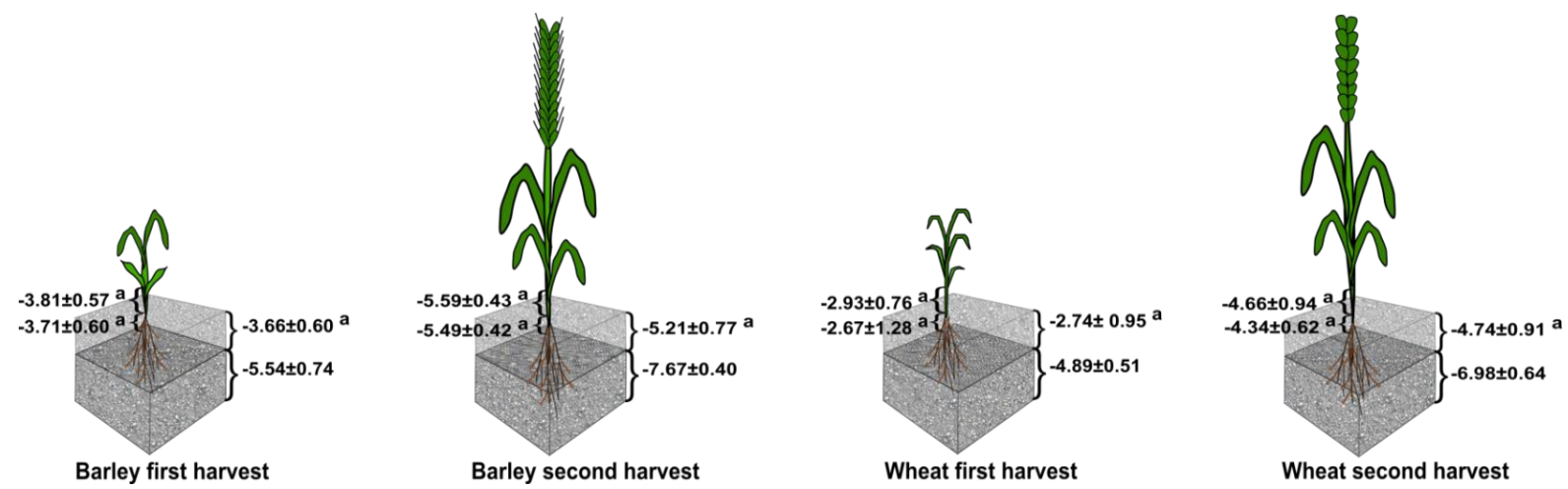

Figure 7. Means and standard deviations of oxygen isotopic composition in per mil in stems, root crowns, soil upper- and lower $8 \mathrm{~cm}$ for barley and wheat at two harvest times. Different letters indicate significant differences $(p<0.05)$.

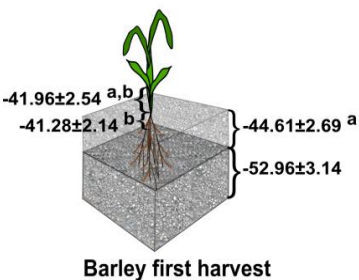

Barley first harvest

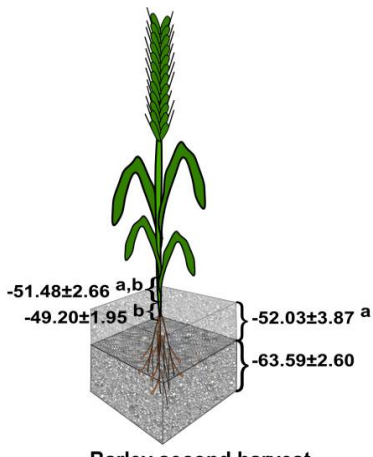

Barley second harvest

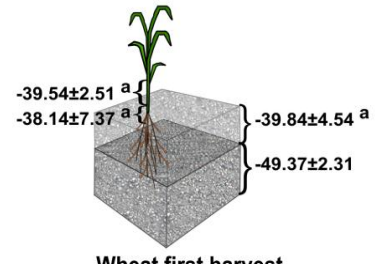

Wheat first harvest

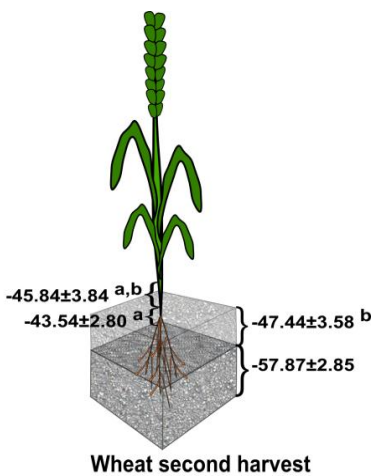

Wheat second harvest

Figure 8. Means and standard deviations of hydrogen isotopic composition in per mil in stems, root crowns, soil upper- and lower $8 \mathrm{~cm}$ for barley and wheat at two harvest times. Letters indicate significant differences $(p<0.05)$.

To date, only a few studies have applied extraction temperatures $>100^{\circ} \mathrm{C}$ (Walker et al., 1994; Araguás-Araguás et al., 1995). Despite using such a high temperature, Walker et al. (1994) could not recover the added water isotopic signature for dry and wet clays, sand, and gypseous sand. Nevertheless, high-temperature extractions yielded smaller deviations of isotopic signatures from the introduced water than low-temperature extractions $\left(35\right.$ to $\left.80^{\circ} \mathrm{C}\right)$. In a later study, Araguás-Araguás et al. (1995) achieved recovery rates $>98 \%$ for pure sand by either increasing the temperature or the extraction time. Thus, we recommend analyzing the potential of high temperature extractions for a complete, fractionation-free retrieval of soil water, especially for clayey soils.

\subsection{Applying cryogenic extraction to investigate crop water uptake}

Quantitative analyses (MANOVAs) - performed for the identification of crop water uptake in various soil depths - revealed that barley and wheat were taking up their water from the upper $8 \mathrm{~cm}$ of the soil column at both harvest times. We found no significant differences in oxygen isotopic signatures between water extracted from stems, root crowns, and the upper $8 \mathrm{~cm}$ of the soil at first and second harvest for both crop species (Fig. 7).

For hydrogen isotopic data, no significant differences between stems and root crowns at both harvest times and for both species could be observed. However, only the hydrogen isotopic signatures of stem tissue water corresponded to that of water from the upper $8 \mathrm{~cm}$ of soil in the experiments with barley at both harvests, and for wheat at the second harvest (Fig. 8). For wheat both plant tissues reflected the upper soil isotopic signatures at first harvest.

Isotopic values were generally more enriched at first harvest for both species. Moreover, root crowns showed more positive $\delta$ values than stems for both isotopes, species, and harvest times (Figs. 7 and 8). Even though a larger rooting depth was observed at second harvest, the majority of roots was found in the upper evaporative soil layer. Therefore, the water from root crowns showed more positive $\delta^{2} \mathrm{H}$ values than that of stems, which was in agreement with the findings of Barnard et al. (2006).

Since evaporative enrichment of soil water is a well-known process under field conditions (Barnard et al., 2006), we decided not to inhibit it and, therefore, did not cover the soil, 
contrary to Walker and Richardson (1991). Due to evaporation the $\delta^{2} \mathrm{H}$ and $\delta^{18} \mathrm{O}$ values of the soil water decreased with depth, while the intensity of this effect was mainly influenced by atmospheric conditions, such as temperature, relative humidity and the soil water content within the pots (Figs. 7 and 8). More bare soil and lower transpiration rates resulted in more enriched $\delta$ values in the upper part of the soil column at the first harvest for both isotopes and consequently also in the water-bearing plant tissues, confirming results by Barnard et al. (2006) for grass species. As a result, soil isotopic signatures did not reflect irrigation water signatures at the first nor at the second harvest.

In general, barley and wheat showed no species-specific or harvest-time effect on the water uptake depth. Stem material reflected more often the isotopic signature of the soil water than root crown tissue. Both observations are contrary to results presented by Barnard et al. (2006). To the author's knowledge there is no common explanation for that phenomenon, since water moves from soil to roots, and then to the stems without isotopic fractionation. Theoretically, the water can be sampled fractionation-free from plant tissues, and is assumed to have the same isotopic signature as the weighted average of soil water (Takahashi, 1998). However, taking the analytical accuracy for $\delta^{2} \mathrm{H}$ into account, which is $\pm 0.6 \%$, the isotopic signatures of root crown and stem material are likely to be similar, resulting in no significant differences to the upper soil isotopic signature. Generally, $\delta^{18} \mathrm{O}$ values yielded more consistent results for the identification of crop water uptake zones than $\delta^{2} \mathrm{H}$. Barnard et al. (2006) stated that the estimation of plant source water is typically based on the comparison of $\delta^{18} \mathrm{O}$ values of plant tissues with that of soil or rain water. In previous studies on water uptake by grass and crop species, either oxygen (Wang and Yakir, 2000; Barnard et al., 2006; Durand et al., 2007; Nippert and Knapp, 2007; Asbjornsen et al., 2007; Rothfuss et al., 2010; Wang et al., 2012) or hydrogen isotopes (Dalton, 1988; Zegada-Lizarazu and Iijima, 2004; Walter and Morio, 2005; Yang et al., 2011) were analyzed. Only few studies analyzed both isotopes (Corbin et al., 2005; Wang et al., 2010; Rossatto et al., 2013). Furthermore, only a small number of out of these studies (Zegada-Lizarazu and Iijima, 2004; Barnard et al., 2006; Rossatto et al., 2013) performed statistical methods comparable to the here presented tests. In order to evaluate results with regard to plant water uptake depths, both isotopes should be analyzed. The calculations from $\delta^{18} \mathrm{O}$ values should not differ significantly from the calculations obtained from $\delta^{2} \mathrm{H}$ values, as verified by Rossatto et al. (2013).

\section{Conclusions}

The functionality tests on the extraction system demonstrated that the extraction system was vacuum-tight, and assured reproducibility, stable extraction conditions and reliable results. Alterations of isotopic signatures due to the extraction procedure itself, cross-contamination between the extraction lines or the high-purity nitrogen purging could be excluded.

Surprisingly, extractions of dried and rehydrated soils revealed significant differences in the isotopic composition of the added and the extracted water. While extraction time and pressure could be excluded, temperature seemed to be the crucial factor for the impossibility of recovering the isotopic signature of the added water. Therefore, the temperature effect on isotopic signatures of extracted water should be carefully scrutinized in future studies applying cryogenic extraction techniques, especially for soils with a high silt and clay content.

Applying cryogenic extraction to quantify water uptake of barley and wheat revealed that these crop species were taking up their water from the upper soil column even at a later growth stage. In order to verify results of plant water uptake calculations and, moreover, to avoid misinterpretation of plant water sources, a comparison of hydrogen and oxygen isotopic data should be performed, which has to generate the same outcome.

Present findings raise the question whether results from different extraction systems and conditions are comparable, for instance in the context of plant water studies. If isotopic data is applied to studies, whose focus is on the mobile water fraction available for plants, Araguás-Araguás et al. (1995) recommended adjusting extraction conditions to lower temperatures and shorter extraction times to keep the effect of weakly bound soil water as low as possible. Extraction errors due to the abovementioned extraction problems implicate an offset of measured isotope values due to fractionation as a consequence of incomplete extraction, or a mixture of different isotopic pools (Araguás-Araguás et al., 1995) when adding water to soil which then mixes with the remaining weakly bound water. Thus, soil water isotopic signatures obtained from vacuum extraction have to be critically compared with those of other water pools, such as precipitation (Kendall and McDonnell, 1998). The ultimate question therefore is: which water are we actually extracting under certain extraction conditions (temperature, pressure, and extraction time) from a specific soil type, and is this fraction of water the one that is utilized by plants or is it a mixture of water pools stored in the soil? 
Table A1. Parts list of extraction system.

\begin{tabular}{|c|c|c|c|c|c|}
\hline Item & Article description & Ordering number & Producer & Quantity & Measures \\
\hline 1 & Laboratory-trolley & 615911 & $\begin{array}{l}\text { Kaiser und Kraft Inc., } \\
\text { Stuttgart, DE }\end{array}$ & 1 & $\begin{array}{l}\text { W: } 2000 \mathrm{~mm} \text {, } \\
\text { D: } 800 \mathrm{~mm}, \mathrm{H}: 940 \mathrm{~mm}\end{array}$ \\
\hline 2 & Vacuum pump, RV5 & A65301903 & $\begin{array}{l}\text { Edwards Inc., } \\
\text { München, DE }\end{array}$ & 1 & \\
\hline 3 & $\begin{array}{l}\text { KF flexible hose to } \\
\text { vacuum pump }\end{array}$ & FX25K100-316 & Vacom Inc., Jena, DE & 1 & $\begin{array}{l}\text { DN 25, L: } 1000 \mathrm{~mm} \text {, } \\
\text { Diameter: } 40 \mathrm{~mm}\end{array}$ \\
\hline 4 & $\begin{array}{l}\text { PIRANI }{ }^{\circledR} \text { vacuum } \\
\text { gauge, VAP 5-set }\end{array}$ & $188-1130$ & $\begin{array}{l}\text { Vacuubrand Inc., } \\
\text { Wertheim, DE }\end{array}$ & 1 & \\
\hline 5 & $\begin{array}{l}\text { Vacuum gauge, DCP } \\
3000+\text { VSK } 3000\end{array}$ & 683170 & $\begin{array}{l}\text { Vacuubrand Inc., } \\
\text { Wertheim, DE }\end{array}$ & 2 & \\
\hline 6 & $\begin{array}{l}\text { Water bath, JB aqua } 18, \\
\text { standard }\end{array}$ & $462-8136$ & $\begin{array}{l}\text { Grant Instruments, } \\
\text { Hillsborough, NJ, US }\end{array}$ & 1 & $\begin{array}{l}\text { Vol: } 18 \mathrm{~L}, \mathrm{~W}: 340 \mathrm{~mm} \text {, } \\
\text { D: } 570 \mathrm{~mm}, \mathrm{H}: 270 \mathrm{~mm}\end{array}$ \\
\hline 7 & Nitrogen cold trap & $478-4302$ & $\begin{array}{l}\text { Reichelt Chemietech- } \\
\text { nik Inc., Heidelberg, } \\
\text { DE }\end{array}$ & 4 & $\begin{array}{l}\text { Vol: 4L, W: } 280 \mathrm{~mm}, \mathrm{D}: \\
190 \mathrm{~mm}, \mathrm{H}: 110 \mathrm{~mm}\end{array}$ \\
\hline 8 & Y-connector, QSMY-3 & 153370 & $\begin{array}{l}\text { Festo Ltd., Esslingen, } \\
\text { DE }\end{array}$ & 5 & Diameter: $3 \mathrm{~mm}$ \\
\hline 8 & $\begin{array}{l}\text { Teflon hose-connection } \\
\text { to nitrogen gas source }\end{array}$ & 741632 & $\begin{array}{l}\text { Riesbeck Inc., } \\
\text { Biebergemünd, DE }\end{array}$ & 1 & Diameter: $3.2 \mathrm{~mm}$ \\
\hline 8 & $\begin{array}{l}\text { Reducing plug } \\
\text { connection, QSM-6-4 }\end{array}$ & 153327 & $\begin{array}{l}\text { Festo Ltd., Esslingen, } \\
\text { DE }\end{array}$ & 1 & Diameter: $6 \mathrm{~mm} \times 4 \mathrm{~mm}$ \\
\hline 9 & $\begin{array}{l}\text { Vacuum manifold } \\
\text { (stainless steel) }\end{array}$ & 316TI-T10M-S-1.5M-6ME & $\begin{array}{l}\text { Swagelok Company, } \\
\text { Solon, OH, US }\end{array}$ & 1 & $\begin{array}{l}\text { Diameter } 10 \mathrm{~mm} \text {, Wall: } \\
1.5 \mathrm{~mm} \text {, L: } 1000 \mathrm{~mm}\end{array}$ \\
\hline 10 & Diaphragm valve & SS-DLS8MM & $\begin{array}{l}\text { Swagelok Company, } \\
\text { Solon, OH, US }\end{array}$ & 12 & Diameter $8 \mathrm{~mm}$ \\
\hline 11 & $\begin{array}{l}\text { KF flexible hoses to } \\
\text { extraction-collection- } \\
\text { units }\end{array}$ & FX16K100-304 & Vacom Inc., Jena, DE & 6 & $\begin{array}{l}\text { DN 16, L: } 1000 \mathrm{~mm} \text {, } \\
\text { Diameter: } 30 \mathrm{~mm}\end{array}$ \\
\hline 12 & KF clamping chain & $710653-1$ & $\begin{array}{l}\text { Rettberg Inc., } \\
\text { Göttingen, DE }\end{array}$ & 54 & DN16 \\
\hline 12 & $\mathrm{KF}$ centering ring & 1340150160 & $\begin{array}{l}\text { Rettberg Inc., } \\
\text { Göttingen, DE }\end{array}$ & 54 & DN16 \\
\hline 12 & KF bored flange & KF16B19-316 & Vacom Inc., Jena, DE & 16 & DN16 \\
\hline 12 & KF clamp ring & KF16C & Vacom Inc., Jena, DE & 16 & DN16 \\
\hline 13 & $\begin{array}{l}\text { Extraction tube made } \\
\text { of DN16 glass flange }\end{array}$ & 1340130160; hand-made & $\begin{array}{l}\text { Rettberg Inc., Göttin- } \\
\text { gen, DE; Glass blow- } \\
\text { ing, JLU Giessen, DE }\end{array}$ & 18 & $\begin{array}{l}\text { Round-bottom, } \\
\text { L: } 120 \mathrm{~mm}\end{array}$ \\
\hline 14 & $\begin{array}{l}\text { U-tube made of DN16 } \\
\text { glass flanges }\end{array}$ & 1340130160; hand-made & $\begin{array}{l}\text { Rettberg Inc., Göttin- } \\
\text { gen, DE; Glass blow- } \\
\text { ing, JLU Giessen, DE }\end{array}$ & 18 & $\begin{array}{l}\mathrm{W}: 180 \text { to } 200.5 \mathrm{~mm} \text {, L: } \\
180 \text { to } 200 \mathrm{~mm} \text {, distance } \\
\text { U-tube arms: } 40.5 \mathrm{~mm}\end{array}$ \\
\hline
\end{tabular}


Acknowledgements. We are thankful to Rolf Siegwolf from the Paul Scherrer Institute (Villigen, $\mathrm{CH}$ ), who gave us valuable insight into cryogenic vacuum extraction techniques. Further appreciation goes to Günther Jennemann from the University of Applied Sciences Mittelhessen (Giessen, DE), who helped us preparing the technical drawings of the cryogenic vacuum extraction device. Thanks also to Paul Königer for the intensive discussions on results we observed. Natalie Orlowski acknowledges funding by the Friedrich-Ebert-Stiftung.

Edited by: G. S. Aluri

Reviewed by: two anonymous referees

\section{References}

Araguás-Araguás, L., Rozanski, K., Gonfiantini, R., and Louvat, D.: Isotope effects accompanying vacuum extraction of soil water for stable isotope analyses, J. Hydrol., 168, 159-171, 1995.

Asbjornsen, H., Mora, G., and Helmers, M. J.: Variation in water uptake dynamics among contrasting agricultural and native plant communities in the Midwestern U.S., Agr. Ecosyst. Environ., 121, 343-356, doi:10.1016/j.agee.2006.11.009, 2007.

Barnard, R. L., De Bello, F., Gilgen, A. K., and Buchmann, N.: The $\delta^{18} \mathrm{O}$ of root crown water best reflects source water $\delta^{18} \mathrm{O}$ in different types of herbaceous species, Rapid Commun. Mass. Sp., 20, 3799-3802, doi:10.1002/rcm.2778, 2006.

Barnes, C. J. and Allison, G. B.: Tracing of water movement in the unsaturated zone using stable isotopes of hydrogen and oxygen, J. Hydrol., 100, 143-176, doi:10.1016/0022-1694(88)90184-9, 1988.

Barrow, N. J. and Whelan, B. R.: A study of a method for displacing soil solution by centrifuging with an immiscible liquid, J. Environ. Qual., 9, 315-319, doi:10.2134/jeq1980.00472425000900020031x, 1980.

Batley, G. and Giles, M.: Solvent displacement of sediment interstitial waters before trace-metal analysis, Water Res., 13, 879-886, doi:10.1016/0043-1354(79)90223-9, 1979.

Brooks, J., R., Barnard, H., R., Coulombe, R., and McDonnell, J., J.: Ecohydrologic separation of water between trees and streams in a Mediterranean climate, Nat. Geosci., 3, 100-104, doi:10.1038/ngeo722, 2009.

Brunner, P., Li, H. T., Kinzelbach, W., Li, W. P., and Dong, X. G.: Extracting phreatic evaporation from remotely sensed maps of evapotranspiration, Water Resour. Res., 44, W08428, doi:10.1029/2007WR006063, 2008.

Butt, S., Ali, M., Fazil, M., and Latif, Z.: Seasonal variations in the isotopic composition of leaf and stem water from an arid region of Southeast Asia, Hydrolog. Sci. J., 55, 844-848, doi:10.1080/02626667.2010.487975, 2010.

Corbin, J. D., Thomsen, M. A., Dawson, T. E., and D'Antonio, C. M.: Summer water use by California coastal prairie grasses: Fog, drought, and community composition, Oecologia, 145, 511-521, doi:10.1007/s00442-005-0152-y, 2005.

Craig, H.: Standard for reporting concentrations of deuterium and oxygen-18 in natural waters, Science, 133, 1833-1834, doi:10.1126/science.133.3467.1833, 1961.

Dalton, F. N.: Plant root water extraction studies using stable isotopes, Plant Soil, 111, 217-221, 1988.
Dawson, T. E. and Ehleringer, J. R.: Streamside trees that do not use stream water, Nature, 350, 335-337, doi:10.1038/350335a0, 1991.

Dawson, T. E. and Ehleringer, J. R.: Isotopic enrichment of water in the "woody" tissues of plants: Implications for plant water source, water uptake, and other studies which use the stable isotopic composition of cellulose, Geochim. Cosmochim. Ac., 57, 3487-3492, doi:10.1016/0016-7037(93)90554-A, 1993.

Dawson, T. E. and Pate, J. S.: Seasonal water uptake and movement in root systems of Australian phraeatophytic plants of dimorphic root morphology: A stable isotope investigation, Oecologia, 107, 13-20, doi:10.1007/BF00582230, 1996.

Durand, J. L., Bariac, T., Ghesquière, M., Biron, P., Richard, P., Humphreys, M., and Zwierzykovski, Z.: Ranking of the depth of water extraction by individual grass plants, using natural ${ }^{18} \mathrm{O}$ isotope abundance, Environ. Exp. Bot., 60, 137-144, doi:10.1016/j.envexpbot.2006.09.004, 2007.

Eggemeyer, K. D., Awada, T., Harvey, F. E., Wedin, D. A., Zhou, X., and Zanner, C. W.: Seasonal changes in depth of water uptake for encroaching trees Juniperus virginiana and Pinus ponderosa and two dominant $\mathrm{C}_{4}$ grasses in a semiarid grassland, Tree Physiol., 29, 157-169, doi:10.1093/treephys/tpn019, 2009.

Ehleringer, J. R. and Dawson, T. E.: Water uptake by plants: Perspectives from stable isotope composition, Plant Cell Environ., 15, 1073-1082, doi:10.1111/j.1365-3040.1992.tb01657.x, 1992.

Gat, J. R., Yakir, D., Goodfriend, G., Fritz, P., Trimborn, P., Lipp, J., Gev, I., Adar, E. and Waisel, Y.: Stable isotope composition of water in desert plants, Plant Soil, 298, 31-45, doi:10.1007/s11104-007-9321-6, 2007.

Gazis, C. and Feng, X.: A stable isotope study of soil water: Evidence for mixing and preferential flow paths, Geoderma, 119, 97-111, 2004.

Goebel, T. S. and Lascano, R. J.: System for high throughput water extraction from soil material for stable isotope analysis of water, Journal of Analytical Sciences, Methods and Instrumentation, 2, 203-207, doi:10.4236/jasmi.2012.24031, 2012.

Hsieh, J. C. C., Savin, S. M., Kelly, E. F., and Chadwick, O. A.: Measurement of soil-water $\delta^{18} \mathrm{O}$ values by direct equilibration with $\mathrm{CO}_{2}$, Geoderma, 82, 255-268, doi:10.1016/S00167061(97)00104-3, 1998.

Ingraham, N. L. and Shadel, C.: A comparison of the toluene distillation and vacuum/heat methods for extracting soil water for stable isotopic analysis, J. Hydrol., 140, 371-387, 1992.

Kendall, C. and McDonnell, J. J. (Eds.): Isotope tracers in catchment hydrology, First edition, Elsevier, Amsterdam, the Netherlands, 1998.

Koehler, G., Wassenaar, L. I., and Hendry, M. J.: An automated technique for measuring $\delta \mathrm{D}$ and $\delta^{18} \mathrm{O}$ values of porewater by direct $\mathrm{CO}_{2}$ and $\mathrm{H}_{2}$ equilibration, Anal. Chem., 72, 5659-5664, doi:10.1021/ac000498n, 2000.

Koeniger, P., Marshall, J. D., Link, T., and Mulch, A.: An inexpensive, fast, and reliable method for vacuum extraction of soil and plant water for stable isotope analyses by mass spectrometry, Rapid Commun. Mass. Sp., 25, 3041-3048, doi:10.1002/rcm.5198, 2011.

Leen, J. B., Berman, E. S. F., Liebson, L., and Gupta, M.: Spectral contaminant identifier for off-axis integrated cavity output spectroscopy measurements of liquid water isotopes, Rev. Sci. Instrum., 83, 044305, doi:10.1063/1.4704843, 2012. 
LGR: Los Gatos Research, http://www.lgrinc.com/, last access: 5 February 2013.

Lin, G. H. and Sternberg, L. da S. L.: Hydrogen isotopic fractionation by plant roots during water uptake in coastal wetland plants, in: Stable isotopes and plant carbon-water relations, edited by: Ehleringer, J. R., Hall, A. E., and Farquhar, G. D., Academic, San Diego, CA, USA, 497-510, 1993.

Lis, G., Wassenaar, L. I., and Hendry, M. J.: High-precision laser spectroscopy $\mathrm{D} / \mathrm{H}$ and ${ }^{18} \mathrm{O} /{ }^{16} \mathrm{O}$ measurements of microliter natural water samples, Anal. Chem., 80, 287-293, doi:10.1021/ac701716q, 2008.

Liu, W., Liu, W., Li, P., Duan, W., and Li, H.: Dry season water uptake by two dominant canopy tree species in a tropical seasonal rainforest of Xishuangbanna, SW China, Agr. Forest Meteorol., 150, 380-388, doi:10.1016/j.agrformet.2009.12.006, 2010.

Liu, Y., Xu, Z., Duffy, R., Chen, W., An, S., Liu, S., and Liu, F.: Analyzing relationships among water uptake patterns, rootlet biomass distribution and soil water content profile in a subalpine shrubland using water isotopes, Eur. J. Soil Biol., 47, 380-386, doi:10.1016/j.ejsobi.2011.07.012, 2011.

McConville, C., Kalin, R. M., and Flood, D.: Direct equilibration of soil water for $\delta^{18} \mathrm{O}$ analysis and its application to tracer studies, Rapid Commun. Mass Sp., 13, 1339-1345, doi:10.1002/(SICI)1097-0231(19990715)13:13<1339::AIDRCM559>3.0.CO;2-N, 1999.

Mubarak, A. and Olsen, R.: Immiscible displacement of soil solution by centrifugation, Soil Sci. Soc. Am. J., 40, 329-331, 1976.

Newman, B., Tanweer, A., and Kurttas, T.: IAEA Standard Operating Procedure for the Liquid-Water Stable Isotope Analyser: available at: http://www-naweb.iaea.org/napc/ ih/documents/other/laser_procedure_rev12.PDF, last access: 10 April 2012.

Nippert, J. B. and Knapp, A. K.: Linking water uptake with rooting patterns in grassland species, Oecologia, 153, 261-272, doi:10.1007/s00442-007-0745-8, 2007.

Penna, D., Stenni, B., Šanda, M., Wrede, S., Bogaard, T. A., Gobbi, A., Borga, M., Fischer, B. M. C., Bonazza, M., and Chárová, Z.: On the reproducibility and repeatability of laser absorption spectroscopy measurements for $\delta 2 \mathrm{H}$ and $\delta 18 \mathrm{O}$ isotopic analysis, Hydrol. Earth Syst. Sci., 14, 1551-1566, doi:10.5194/hess-141551-2010, 2010.

Peters, L. I. and Yakir, D.: A direct and rapid leaf water extraction method for isotopic analysis, Rapid Commun. Mass Sp., 22, 2929-2936, doi:10.1002/rcm.3692, 2008.

Phillips, D. L. and Gregg, J. W.: Source partitioning using stable isotopes: coping with too many sources, Oecologia, 136, 261269, doi:10.1007/s00442-003-1218-3, 2003.

Revesz, K. and Woods, P. H.: A method to extract soil water for stable isotope analysis, J. Hydrol., 115, 397-406, 1990.

Rossatto, D. R., Ramos Silva, L. de C., Villalobos-Vega, R., Sternberg, L. da S. L., and Franco, A. C.: Depth of water uptake in woody plants relates to groundwater level and vegetation structure along a topographic gradient in a neotropical savanna, Environ. Exp. Bot., 77, 259-266, doi:10.1016/j.envexpbot.2011.11.025, 2012.

Rossatto, D. R., Sternberg, L. da S. L., and Franco, A. C.: The partitioning of water uptake between growth forms in a Neotropical savanna: Do herbs exploit a third water source niche?, Plant Biol., 15, 84-92, doi:10.1111/j.1438-8677.2012.00618.x, 2013.
Rothfuss, Y., Biron, P., Braud, I., Canale, L., Durand, J.-L., Gaudet, J.-P., Richard, P., Vauclin, M., and Bariac, T.: Partitioning evapotranspiration fluxes into soil evaporation and plant transpiration using water stable isotopes under controlled conditions, Hydrol. Process., 24, 3177-3194, doi:10.1002/hyp.7743, 2010.

Rothfuss, Y., Braud, I., Le Moine, N., Biron, P., Durand, J.L., Vauclin, M., and Bariac, T.: Factors controlling the isotopic partitioning between soil evaporation and plant transpiration: Assessment using a multi-objective calibration of SiSPATIsotope under controlled conditions, J. Hydrol., 442-443, 75-88, doi:10.1016/j.jhydrol.2012.03.041, 2012.

Sala, O. E., Jackson, R. B., Mooney, H. A., and Howarth, R. W. (Eds.): Methods in Ecosystem Science, Springer, New York, USA, 2000.

Schultz, N. M., Griffis, T. J., Lee, X., and Baker, J. M.: Identification and correction of spectral contamination in ${ }^{2} \mathrm{H} /{ }^{1} \mathrm{H}$ and ${ }^{18} \mathrm{O} /{ }^{16} \mathrm{O}$ measured in leaf, stem, and soil water, Rapid Commun. Mass Sp., 25, 3360-3368, doi:10.1002/rcm.5236, 2011.

Scrimgeour, C. M.: Measurement of plant and soil water isotope composition by direct equilibration methods, J. Hydrol., 172, 261-274, doi:10.1016/0022-1694(95)02716-3, 1995.

Song, X., Wang, S., Xiao, G., Wang, Z., Liu, X., and Wang, P.: A study of soil water movement combining soil water potential with stable isotopes at two sites of shallow groundwater areas in the North China Plain, Hydrol. Process., 23, 1376-1388, doi:10.1002/hyp.7267, 2009.

Stratton, L. C., Goldstein, G., and Meinzer, F. C.: Temporal and spatial partitioning of water resources among eight woody species in a Hawaiian dry forest, Oecologia, 124, 309-317, doi:10.1007/s004420000384, 2000.

Takahashi, K.: Oxygen isotope ratios between soil water and stem water of trees in pot experiments, Ecol. Res., 13, 1-5, doi:10.1046/j.1440-1703.1998.00240.x, 1998.

Thorburn, P. J. and Ehleringer, J. R.: Root water uptake of fieldgrowing plants indicated by measurements of natural-abundance deuterium, Plant Soil, 177, 225-233, 1995.

Thorburn, P. J., Walker, G. R., and Brunel, J.-P: Extraction of water from Eucalyptus trees for analysis of deuterium and oxygen18: laboratory and field techniques, Plant Cell Environ., 16, 269 277, doi:10.1111/j.1365-3040.1993.tb00869.x, 1993.

Unkovich, M., Pate, J., McNeill, A., and Gibbs, J.: Stable isotope techniques in the study of biological processes and functioning of ecosystems, Kluwer Academic Publishers, Dordrecht, the Netherlands, 2001.

Vendramini, P. F. and Sternberg, L. da S. L.: A faster plant stemwater extraction method, Rapid Commun. Mass Sp., 21, 164168, doi:10.1002/rcm.2826, 2007.

Walker, C. D. and Richardson, S. B.: The use of stable isotopes of water in characterising the source of water in vegetation, Chem. Geol.: Isotope Geoscience section, 94, 145-158, 1991.

Walker, G. R., Woods, P. H., and Allison, G. B.: Interlaboratory comparison of methods to determine the stable isotope composition of soil water, Chem. Geol., 111, 297-306, 1994.

Walter, Z.-L. and Morio, I.: Deep root water uptake ability and water use efficiency of pearl millet in comparison to other millet species, Plant Prod. Sci., 8, 454-460, 2005.

Wang, P., Song, X., Han, D., Zhang, Y., and Liu, X.: A study of root water uptake of crops indicated by hydrogen and oxygen stable 
isotopes: A case in Shanxi Province, China, Agr. Water Manage., 97, 475-482, 2010.

Wang, P., Song, X., Han, D., Zhang, Y., and Zhang, B.: Determination of evaporation, transpiration and deep percolation of summer corn and winter wheat after irrigation, Agr. Water Manage., 105, 32-37, doi:10.1016/j.agwat.2011.12.024, 2012.

Wang, X. F. and Yakir, D.: Using stable isotopes of water in evapotranspiration studies, Hydrol. Process., 14, 1407-1421, 2000.

Wassenaar, L. I., Hendry, M. J., Chostner, V. L., and Lis, G. P.: High resolution pore water $\delta^{2} \mathrm{H}$ and $\delta^{18} \mathrm{O}$ measurements by $\mathrm{H}_{2} \mathrm{O}$ (liquid) $-\mathrm{H}_{2} \mathrm{O}$ (vapor) equilibration laser spectroscopy, Environ. Sci. Technol., 42, 9262-9267, 2008.

Wershaw, R. L., Friedman, I., Heller, S. J., and Frank, P. A.: Hydrogen isotopic fractionation of water passing through trees, in: Advances in organic geochemistry, International series of monographs on earth sciences, edited by: Hobson, G. D., Speers, G. C., and Inderson, D. E., 32, Pergamon Press, New York, USA, 55-67, 1966.

West, A. G., Patrickson, S. J., and Ehleringer, J. R.: Water extraction times for plant and soil materials used in stable isotope analysis, Rapid Commun. Mass Sp., 20, 1317-1321, doi:10.1002/rcm.2456, 2006.
West, A. G., Goldsmith, G. R., Brooks, P. D., and Dawson, T. E.: Discrepancies between isotope ratio infrared spectroscopy and isotope ratio mass spectrometry for the stable isotope analysis of plant and soil waters, Rapid Commun. Mass Sp., 24, 1948-1954, doi:10.1002/rcm.4597, 2010.

White, J. W. C., Cook, E. R., Lawrence, J. R., and Wallace S. B.: The $\mathrm{D} / \mathrm{H}$ ratios of sap in trees: Implications for water sources and tree ring $\mathrm{D} / \mathrm{H}$ ratios, Geochim. Cosmochim. Ac., 49, 237-246, doi:10.1016/0016-7037(85)90207-8, 1985.

Williams, D. G. and Ehleringer, J. R.: Intra- and interspecific variation for summer precipitation use in pinyon-juniper woodlands, Ecol. Monogr., 70, 517-537, doi:10.2307/2657185, 2000.

Yang, H., Auerswald, K., Bai, Y., and Han, X.: Complementarity in water sources among dominant species in typical steppe ecosystems of Inner Mongolia, China, Plant Soil, 340, 303-313, doi:10.1007/s11104-010-0307-4, 2011.

Zegada-Lizarazu, W. and Iijima, M.: Hydrogen stable isotope analysis of water acquisition ability of deep roots and hydraulic lift in sixteen food crop species, Plant. Prod. Sci., 7, 427-434, doi:10.1626/pps.7.427, 2004. 